\title{
A novel thermophilic hemoprotein scaffold for rational design of biocatalysts
}

\author{
Joana Efua Aggrey-Fynn ${ }^{1} \cdot$ Nur Basak Surmeli ${ }^{2}$
}

Received: 28 April 2018 / Accepted: 3 September 2018 / Published online: 12 September 2018

(c) SBIC 2018

\section{Abstract}

Hemoproteins are commonly found in nature, and involved in many important cellular processes such as oxygen transport, electron transfer, and catalysis. Rational design of hemoproteins can not only inspire novel biocatalysts but will also lead to a better understanding of structure-function relationships in native hemoproteins. Here, the heme nitric oxide/oxygen-binding protein from Caldanaerobacter subterraneus subsp. tengcongensis (Tt $\mathrm{H}-\mathrm{NOX}$ ) is used as a novel scaffold for oxidation biocatalyst design. We show that signaling protein $T t \mathrm{H}-\mathrm{NOX}$ can be reengineered to catalyze $\mathrm{H}_{2} \mathrm{O}_{2}$ decomposition and oxidation of 2,2'-azino-bis(3-ethylbenzothiazoline-6-sulphonic acid) by $\mathrm{H}_{2} \mathrm{O}_{2}$. In addition, the role of the distal tyrosine (Tyr140) in catalysis is investigated. The mutation of Tyr140 to alanine hinders the catalysis of the oxidation reactions. On the other hand, the mutation of Tyr140 to histidine, which is commonly observed in peroxidases, leads to a significant increase of the catalytic activity. Taken together, these results show that, while the distal histidine plays an important role in hemoprotein reactions with $\mathrm{H}_{2} \mathrm{O}_{2}$, it is not always essential for oxidation activity. We show that $T t \mathrm{H}-\mathrm{NOX}$ protein can be used as an alternative scaffold for the design of novel biocatalysts with desired reactivity or functionality.

Graphical abstract H-NOX proteins are homologous to the nitric oxide sensor soluble guanylate cyclase. Here, we show that the gas sensor protein $T t \mathrm{H}-\mathrm{NOX}$ shows limited capacity for catalysis of redox reactions and it can be used as a novel scaffold in biocatalysis design.

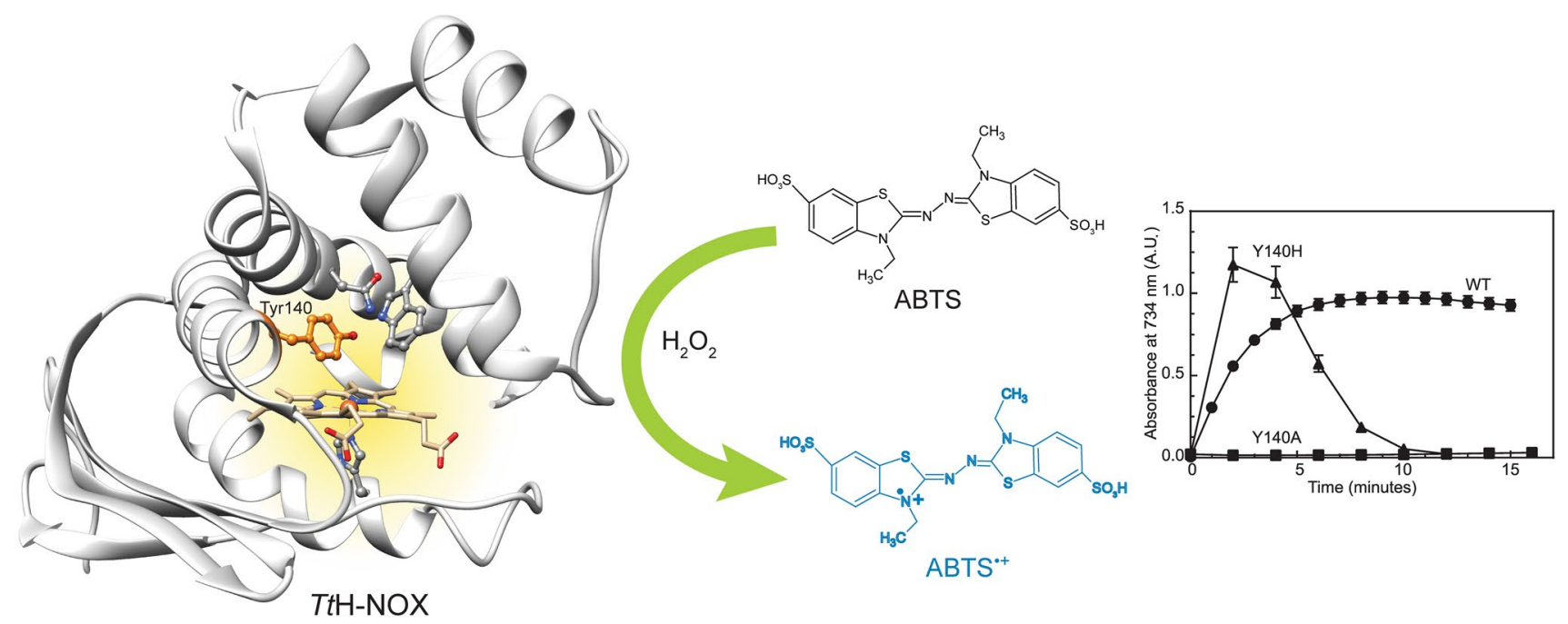

Electronic supplementary material The online version of this article (https://doi.org/10.1007/s00775-018-1615-z) contains supplementary material, which is available to authorized users.

Extended author information available on the last page of the article 
Keywords Hemoproteins $\cdot$ Protein engineering $\cdot$ Heme nitric oxide/oxygen-binding protein $\cdot$ Peroxidase $\cdot$ Enzymes

\section{Abbreviations}

H-NOX Heme nitric oxide/oxygen binding

$T t \mathrm{H}-\mathrm{NOX}$ Heme domain of the methyl-accepting chemotaxis protein from Caldanaerobacter subterraneus subsp. tengcongensis

$\mathrm{Mb} \quad$ Myoglobin

HRP Horseradish peroxidase

ABTS 2,2'-Azino-bis(3-ethylbenzothiazoline-6-sulphonic acid)

WT Wild type

SDM Site-directed mutagenesis

IPTG Isopropyl $\beta$-D-1-thiogalactopyranoside

ALA 5-Aminolevulinic acid hydrochloride

\section{Introduction}

Hemoproteins contain the iron protoporphyrin IX as a prosthetic group [1]. They have diverse roles in oxygen transport (e.g., hemoglobin and myoglobin), signaling (e.g., soluble guanylate cyclase), electron transfer (cytochrome b5), and catalysis (e.g., NO synthase, cytochrome P450, catalase, and NO reductase) [2-6]. Understanding the factors that determine the hemoprotein activity remains a challenge [7]. Biochemical, biophysical, and chemical studies have shown that the type of reactions catalyzed by hemoproteins and their variants are influenced by the proximal axial ligand, its surrounding amino acid residues, the distal pocket arrangements, and the type of heme [8]. One approach to understand how the axial ligand and distal pocket affects hemoprotein activity is the introduction of new activities to non-enzymatic hemoproteins.

Peroxidases are hemoproteins that use hydrogen peroxide $\left(\mathrm{H}_{2} \mathrm{O}_{2}\right)$ to oxidize various endogenous and exogenous substrates. Applications of peroxidases in synthetic organic chemistry for regioselective and enantioselective oxidations are very appealing and an active area of research $[9,10]$. The previous studies on the reaction of peroxidases with $\mathrm{H}_{2} \mathrm{O}_{2}$ show that the reaction can result in the formation a ferryl porphyrin cation radical $\left(\mathrm{Fe}^{\mathrm{IV}}=\mathrm{O} \mathrm{Por}^{+*}\right)$ intermediate known as compound I [11-13]. Compound I is formed through the heterolytic cleavage of the peroxide bond. Compound I can be reduced to compound II, a ferryl porphyrin $\left(\mathrm{Fe}^{\mathrm{IV}}=\mathrm{O}\right.$ Por $)$ species. Partial homolysis of the peroxide bond in $\mathrm{H}_{2} \mathrm{O}_{2}$ can also form compound II [12]. Introduction of peroxidase activity to a new hemoprotein scaffold can generate novel enzymes that can have applications from fine chemical synthesis to environmental biocatalysis and also aid in understanding of structure-function relationships in these enzymes.
A frontier goal of hemoprotein investigation is to leverage mechanistic understanding to design novel activities in the hemoprotein scaffold. Rational design by site-directed mutagenesis involves remodeling protein activity by introducing mutations based on structure and previous investigations [7, 8, 14]. Rational design has been utilized to understand the structural differences and reaction mechanisms of peroxidases. By redesigning the heme active site, myoglobin $(\mathrm{Mb})$ can be converted to a peroxidase [12, 15-17].

In this study, we introduce an alternative scaffold for rational hemoprotein design. Our ideal scaffold improves upon the myoglobin precedent by being thermophilic, amenable to large-scale production, stable in harsh conditions (temperature, $\mathrm{pH}$, aqueous solutions, and organic solvents), and tolerant of mutations. As a candidate scaffold, we explored a member of the heme nitric oxide/oxygen-binding (H-NOX) protein family. The H-NOX protein family, which is largely found in prokaryotes, was discovered due to their 15-40\% sequence homology to eukaryotic nitric oxide sensor soluble guanylate cyclase [18-20]. The H-NOX protein in this study is a subunit of the methyl-accepting chemotaxis protein from the thermophilic and anaerobic bacteria Caldanaerobacter subterraneus subsp. tengcongensis. $T t \mathrm{H}-\mathrm{NOX}$ is one of the most well-studied members of the H-NOX family due to its ease of expression, stability, and robustness towards mutations [20-24]. The crystal structure of $T t \mathrm{H}-\mathrm{NOX}$ has already been determined at $1.77 \AA$ resolution which can aid in the rational design [21]. Here, we investigate the catalytic potential of $T t \mathrm{H}-\mathrm{NOX}$ proteins.

Protein residues around the heme group play important roles in the reaction between $\mathrm{H}_{2} \mathrm{O}_{2}$ and hemoproteins [25, 26]. To investigate the role of different residues in the reaction of hydrogen peroxide with hemoproteins, the distal pocket of some of the heme proteins is compared in Fig. 1. Peroxidases and globins contain a critical histidine residue in the distal pocket. In peroxidases, the distal histidine acts as an acid-base catalyst by removing a proton from the peroxide bonded to the heme iron and delivering a proton to the leaving $\mathrm{O}$ group [27]. On the other hand, $\mathrm{Mb}$ evolved to be an oxygen carrier rather than react with $\mathrm{H}_{2} \mathrm{O}_{2}$; therefore, the distal histidine found in $\mathrm{Mb}$ is too close to the heme iron to facilitate compound I formation [18-20].

Compared to globins and peroxidases, $T t \mathrm{H}-\mathrm{NOX}$ proteins have a very different architecture in their distal cavity (Fig. 1). There is no histidine in the distal pocket; however, a critical tyrosine residue is thought to play an important role in substrate binding. Here, we investigate the catalytic potential of such a unique heme pocket architecture. Sitedirected mutagenesis at the distal tyrosine of $T t \mathrm{H}-\mathrm{NOX}$ was performed to investigate its effects on peroxidase activity. In 
Fig. 1 Superposition of the heme and some selected residues in crystal structures of $T t \mathrm{H}-\mathrm{NOX}$ (H-NOX, ball and stick, PDB ID:1U4H) and Mb (thin line, a, PDB ID:1MBO) or horseradish peroxidase (HRP, PDB ID:1ATJ) (thin line, $\mathbf{b})$ including distal tyrosine (Tyr140 in $T t \mathrm{H}-\mathrm{NOX}$ ) and histidine (His64 in Mb, A; His42 in HRP, b) $[21,28,29]$
A
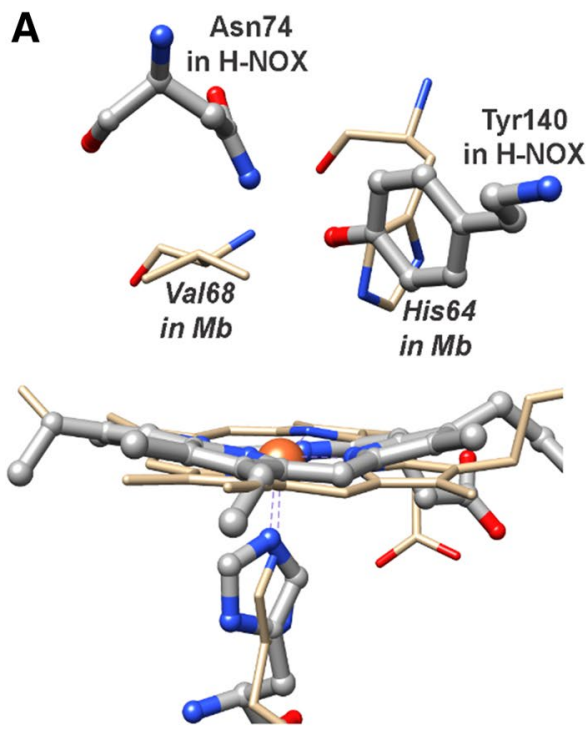

B

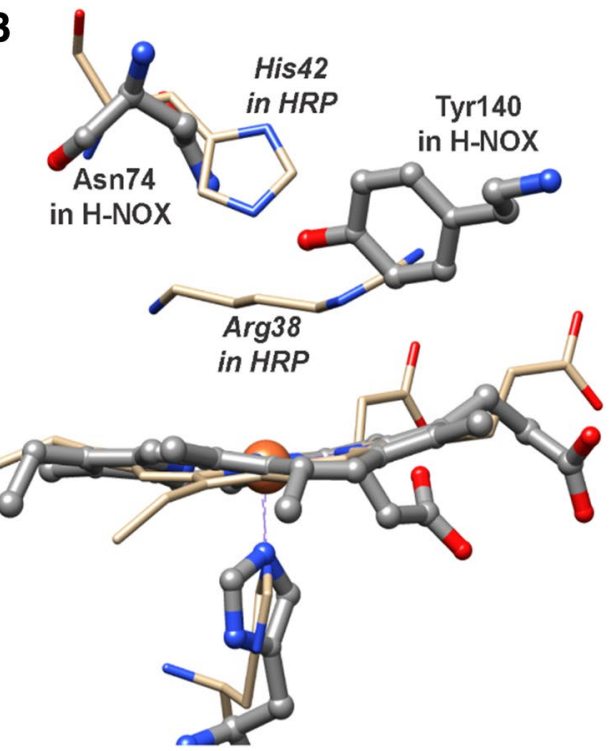

doing so, we seek to not only design a novel biocatalyst, but most importantly, to gain knowledge in understanding the molecular requirements for the catalytic activities of heme enzymes.

\section{Materials and methods}

\section{Cloning, protein expression, and purification}

The Tt $\mathrm{H}-\mathrm{NOX} \mathrm{Y} 140 \mathrm{~A}$ and $\mathrm{Y} 140 \mathrm{H}$ mutants were constructed from the pET20b expression vector containing wild-type (WT) $T t \mathrm{H}-\mathrm{NOX}$ with a C-terminal histidine tag (a gift from the Marletta Laboratory at the University of California, Berkeley, USA). The Tyr140 to alanine and histidine mutations were introduced by the polymerase chain reaction (PCR)-based site-directed mutagenesis (SDM) method using the Q $5^{\circledR}$ Site-Directed Mutagenesis Kit (New England Biolabs). The mutations were confirmed by sequencing of the isolated plasmids.

Expression of $T t \mathrm{H}-\mathrm{NOX}$ and variants was performed as previously described with the following modifications [30]. BL21 (DE3) E. coli harboring the TtH-NOX expression vector were inoculated 1:200 from saturated starter culture into $1 \mathrm{~L}$ Terrific Broth supplemented with $0.1 \mathrm{mg} \mathrm{mL}-1$ ampicillin. Cultures were grown with shaking at $37{ }^{\circ} \mathrm{C}$ to an $\mathrm{OD}_{600 \mathrm{~nm}}$ of 0.8 . Protein expression and heme biosynthesis were then induced using isopropyl $\beta$-D1-thiogalactopyranoside (IPTG) and 5-aminolevulinic acid hydrochloride (ALA) to a final concentration of $0.1 \mathrm{mM}$ and $1 \mathrm{mM}$, respectively. Cultures were grown overnight at $25^{\circ} \mathrm{C}$ and then harvested by centrifugation.

Purification of the WT and mutant $T t \mathrm{H}-\mathrm{NOXs}$ was performed as previously described with the following modifications [30]. Cells were lysed in $50 \mathrm{mM}$ triethanolamine (TEA), $300 \mathrm{mM} \mathrm{NaCl}, 10 \mathrm{mM}$ imidazole, $0.2 \mathrm{mM}$ phenylmethane sulfonyl fluoride (PMSF), and $1 \mathrm{mM}$ benzamidine $\mathrm{HCl}$ at $\mathrm{pH} 7.5$ (buffer A). Lysates were heat denatured at $70{ }^{\circ} \mathrm{C}$ for $40 \mathrm{~min}$ and then pelleted at $3900 \times \mathrm{g}$ for $2 \mathrm{~h}$. The supernatants were applied to pre-equilibrated (with buffer A) Nickel-NTA resin in Gravity-Flow HisPur columns (Thermo Scientific). Washes were then performed with 25-30 column volumes of buffer A until the wavelength at $280 \mathrm{~nm}$ was stable. The $T t \mathrm{H}-\mathrm{NOX}$ proteins were eluted in $50 \mathrm{mM}$ TEA, $150 \mathrm{mM}$ imidazole, and $300 \mathrm{mM}$ $\mathrm{NaCl}, \mathrm{pH}$ 7.5. Subsequently, the proteins were desalted into $50 \mathrm{mM}$ TEA, $20 \mathrm{mM} \mathrm{NaCl}$, and $5 \%$ glycerol using Pierce $^{\mathrm{TM}}$ polyacrylamide desalting columns (Thermo Scientific). Purified proteins were then concentrated to $<2 \mathrm{~mL}$ in $10 \mathrm{~mL}$ Microsep Advance Centrifugal Concentration Tubes with MWCO $3 \mathrm{kDa}$ and aliquots were stored at $-80{ }^{\circ} \mathrm{C}$. Final protein purity was assessed by SDS-PAGE.

\section{Measurement of TtH-NOX heme concentration and extinction coefficients}

The extinction coefficient for WT $T t \mathrm{H}-\mathrm{NOX}$ heme Soret absorbance at $416 \mathrm{~nm}$ has been previously determined to be $89 \mathrm{mM}^{-1} \mathrm{~cm}^{-1}$ [20]. The extinction coefficient of heme Soret absorbance of Y140A and Y140H Tt H-NOX mutants was calculated by determination of the heme concentration of a protein sample with known absorbance. The heme concentrations were determined by the previously established pyridine hemochromagen assay [31]. 


\section{Cyanide binding to WT, oxidized WT, Y140A, and Y140H TtH-NOX}

All cyanide-binding experiments were carried out in $50 \mathrm{mM}$ phosphate buffer at $\mathrm{pH} 7.5$ and $25^{\circ} \mathrm{C}$. The $\mathrm{KCN}$ solutions were prepared freshly before use. UV-Visible spectrophotometric analysis was carried out using a UV-1600PC Scanning Spectrophotometer for the WT and mutant TtH-NOXs.

\section{Oxidation of WT TtH-NOX}

WT $T t \mathrm{H}-\mathrm{NOX}$ is used as isolated unless otherwise noted. Oxidation of WT TtH-NOX was performed under anaerobic environment. The oxidized WT TtH-NOX was obtained by incubation of protein with $20 \mathrm{mM}$ potassium ferricyanide for $30 \mathrm{~min}$ at room temperature. Excess potassium ferricyanide and product ferrocyanide were removed by desalting with Zeba $^{\mathrm{TM}}$ Spin Desalting Columns (Thermo Scientific).

\section{Reactions of TtH-NOX with hydrogen peroxide}

Spectroscopic changes of the WT and mutant TtH-NOXs during the decomposition of $\mathrm{H}_{2} \mathrm{O}_{2}$ were measured at $25^{\circ} \mathrm{C}$ in $50 \mathrm{mM}$ potassium phosphate buffer $(\mathrm{pH} \mathrm{7.0)}$ at time points of $0,1,5,10,15,20,30,40,60$, and $120 \mathrm{~min}$ on a UV-1600PC spectrophotometer. The reaction mixture contained $0.1 \mathrm{mM} \mathrm{H}_{2} \mathrm{O}_{2}, 10 \mu \mathrm{M}$ WT or $10 \mu \mathrm{M} \mathrm{Y} 140 \mathrm{~A}$ or $10 \mu \mathrm{M} \mathrm{Y} 140 \mathrm{H} T t \mathrm{H}-\mathrm{NOXs}$. At every time point, $20 \mu \mathrm{L}$ aliquots of the reaction mixture were collected, frozen, and stored at $-80{ }^{\circ} \mathrm{C}$ for $\mathrm{H}_{2} \mathrm{O}_{2}$ quantification using the Quantitative Peroxide Assay: Aqueous Compatible Formulation Kit (Pierce) with absorbance measurements taken on the FLUOstar Omega Plate Reader at $595 \mathrm{~nm}$. The amount of $\mathrm{H}_{2} \mathrm{O}_{2}$ in the assay at each time point for the $T t \mathrm{H}-\mathrm{NOX}$ was calculated using a standard curve. At least two independent experiments were performed for each time point.

\section{Catalytic Oxidation of 2,2'-azino-bis(3-ethylbenzo- thiazoline-6-sulphonic acid) (ABTS) and guaiacol}

The spectroscopic changes for the one-electron oxidation of ABTS by the WT and mutant $T t \mathrm{H}-\mathrm{NOXs}$ in the presence of $\mathrm{H}_{2} \mathrm{O}_{2}$ in $50 \mathrm{mM}$ potassium phosphate buffer $(\mathrm{pH}$ 7.5) were followed at 380-950 nm at $1 \mathrm{~min}$ intervals. The same procedure is applied for guaiacol oxidation with exception as spectra are followed from 350 to $650 \mathrm{~nm}$. The reaction mixture contained $1 \mathrm{mM} \mathrm{ABTS} \mathrm{(or} 5 \mathrm{mM}$ guaiacol), $1 \mathrm{mM} \mathrm{H}_{2} \mathrm{O}_{2}$, and $3 \mu \mathrm{M} T t \mathrm{H}-\mathrm{NOX}$ proteins. The rate of the ABTS cation radical $\left(\mathrm{ABTS}^{\cdot+}\right)$ formation by $\mathrm{WT}, \mathrm{Y} 140 \mathrm{~A}$, and $\mathrm{Y} 140 \mathrm{H}$ $T t \mathrm{H}-\mathrm{NOX}$ was also monitored at $734 \mathrm{~nm}\left(\varepsilon_{734}=1.5 \times 10^{4}\right.$ $\mathrm{M}^{-1} \mathrm{~cm}^{-1}$ ) where the absorption of $\mathrm{H}-\mathrm{NOX}$ is negligible [32]. The rate of tetraguaiacol formation is followed at $470 \mathrm{~nm}\left(\varepsilon_{470}=2.66 \times 10^{4} \mathrm{M}^{-1} \mathrm{~cm}^{-1}\right)[33]$.

\section{Determination of the kinetic parameters}

In the determination of observed rate constants $\left(k_{\mathrm{obs}}\right)$, the data are fit to one-phase exponential decay equation shown in Eq. 1, where $k$ is the $k_{\text {obs }}$ obtained:

$y=\left(y_{0}-\right.$ Plateau $) \times e^{-k x}+$ Plateau.

All initial rates were determined by linear fitting of the $\mathrm{ABTS}^{\circ+}$ formation in the first $20 \mathrm{~s}$ of the reaction. The $\mathrm{ABTS}^{\circ+}$ formation was monitored at $734 \mathrm{~nm}$ at $0.5 \mathrm{~s}$ intervals.

To determine the kinetic parameters of the ABTS oxidation activity of WT $T t \mathrm{H}-\mathrm{NOX}$, reaction assays of $3 \mu \mathrm{M} \mathrm{WT}$ $T t \mathrm{H}-\mathrm{NOX}, 1.5 \mathrm{mM} \mathrm{H}_{2} \mathrm{O}_{2}$, and variable ABTS concentrations of $0.05-1 \mathrm{mM}$ in $50 \mathrm{mM}$ potassium phosphate buffer of $\mathrm{pH} 7.5$ were prepared. The initial rates obtained were fit to the Michaelis-Menten equation shown in Eq. $2 ; k_{\text {cat }}$ was obtained by dividing the obtained $v_{\max }$ by the protein concentration:

$y=v_{\max } \times x /\left(K_{\mathrm{M}}+x\right)$.

At least two independent measurements were performed for each experiment. GraphPad Prism Software Version 7.04 (GraphPad Software Inc., San Diego, USA) was used for curve fitting the data.

\section{pH dependence of peroxidase activity of WT TtH-NOX}

To determine the $\mathrm{pH}$ dependence of the peroxidase activity of WT TtH-NOX, reaction mixtures containing $5 \mu \mathrm{M}$ WT $T t \mathrm{H}-\mathrm{NOX}, 1 \mathrm{mM}$ ABTS, and $1 \mathrm{mM} \mathrm{H}_{2} \mathrm{O}_{2}$ in a $50 \mathrm{mM}$ potassium phosphate buffer at pHs 5.8, 6.8, 7.5, and 8.0 were prepared. The $\mathrm{ABTS}^{\circ+}$ formation was monitored at $734 \mathrm{~nm}$ for $15 \mathrm{~min}$ at $0.5 \mathrm{~s}$ intervals. The average rates $( \pm \mathrm{SD})$ at each $\mathrm{pH}$ value were determined. At least two experiments were performed for experiment.

\section{Results}

\section{Electronic absorption spectroscopy of WT TtH-NOX and distal tyrosine mutants $\mathrm{Y} 140 \mathrm{~A}$ and $\mathrm{Y} 140 \mathrm{H}$}

Here, the potential for $T t \mathrm{H}-\mathrm{NOX}$ protein as a novel scaffold for generation of biocatalysts is investigated. The focus of this study is catalysis of oxidation reactions with hydrogen peroxide $\left(\mathrm{H}_{2} \mathrm{O}_{2}\right)$. The residues in the distal pocket of heme group play important roles in the reaction between $\mathrm{H}_{2} \mathrm{O}_{2}[24$, 25]. The previous studies have shown that the distal tyrosine (Y140) plays an important role in $\mathrm{O}_{2}$ binding to $T t \mathrm{H}$ NOX $[34,35]$. Since $\mathrm{H}_{2} \mathrm{O}_{2}$ is expected to occupy the distal 
pocket in a similar manner, we decided to investigate the effects of mutations at Tyr 140 on $T t \mathrm{H}-\mathrm{NOX}$ reactions with $\mathrm{H}_{2} \mathrm{O}_{2}$. To understand the possible role of Tyr140 in reaction with $\mathrm{H}_{2} \mathrm{O}_{2}$, we substituted this residue with alanine to eliminate any side-chain interactions (Y140A $T t \mathrm{H}$-NOX). In peroxidases, the distal pocket contains a critically important histidine residue, which acts as an acid-base catalyst [26]. Therefore, we decided to investigate if introduction of a histidine to the distal pocket of $T t \mathrm{H}-\mathrm{NOX}$ can improve catalysis in $\mathrm{H}_{2} \mathrm{O}_{2}$ reactions. Since Tyr140 is within hydrogen-bonding distance to the heme-bound oxygen, we decided to test the catalytic activity of $\mathrm{Y} 140 \mathrm{H}$ mutant of $T t \mathrm{H}-\mathrm{NOX}$.

To this end, TtH-NOX Y140A and Y140H mutants were generated by SDM. Protein expression and purification were performed as previously reported for WT TtH-NOX $[20,36]$. The optical spectra of WT, Y140H, and Y140A mutants of $T t \mathrm{H}-\mathrm{NOX}$ in the ferrous oxy state are shown in Fig. 2. The extinction coefficients of the heme Soret were obtained by quantification of heme using the pyridine hemochromagen assay. WT TtH-NOX shows maximum Soret absorbance at $415 \mathrm{~nm}$ and split $\alpha / \beta$ bands as isolated, similar to previously reported spectra [20]. Mutation of the distal tyrosine to alanine resulted in a shift in the Soret maximum absorbance from 415 to $409 \mathrm{~nm}$. In contrast, the Soret absorbance did not change significantly for the $\mathrm{Y} 140 \mathrm{H}$ variant $(416 \mathrm{~nm})$, while modest splitting of the alpha-beta $(\alpha / \beta)$ region is observed.

Cyanide binding to ferric hemoproteins induces changes in the UV-visible spectra. Indeed, binding of cyanide to ferric $T t \mathrm{H}-\mathrm{NOX}$ results in a shift in Soret absorbance from 415 to $420 \mathrm{~nm}$ [36]. WT and Y140A TtH-NOX showed the UV-visible spectra observed in Fig. 2 as isolated. Since the addition of $\mathrm{KCN}$ to WT and Y140A TtH-NOX as isolated did not result in any significant changes to the Soret

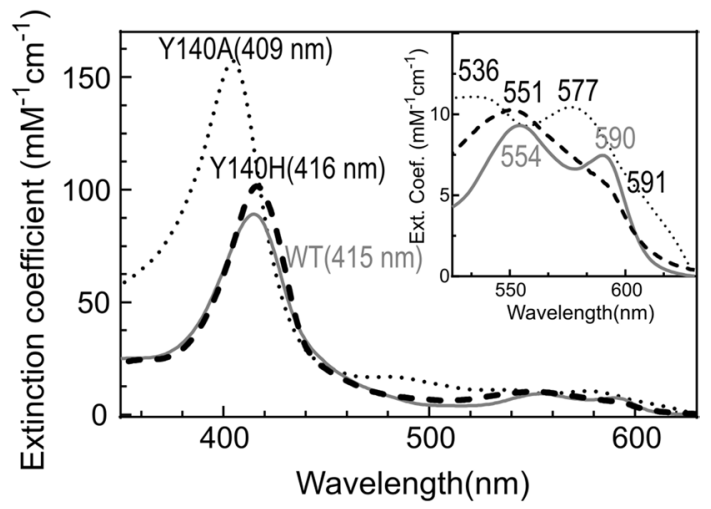

Fig. 2 UV-visible spectra of WT TtH-NOX and distal tyrosine mutants $\mathrm{Y} 140 \mathrm{H}$ and Y140A. Changes observed in the UV-visible spectra of $T t \mathrm{H}-\mathrm{NOX}$ (straight line) when the distal tyrosine is replaced with histidine (Y140H, dashed line) and alanine (Y140A, dotted line) in the ferrous oxy state. Inset: The changes observed in the alpha-beta region absorbance (Fig. S1); it was concluded that these proteins were isolated in the ferrous oxy state. However, $\mathrm{Y} 140 \mathrm{H} T t \mathrm{H}-$ NOX showed maximum Soret absorbance at $410 \mathrm{~nm}$ (Fig. S2) as isolated, and the Soret absorbance of $\mathrm{Y} 140 \mathrm{H}$ showed a significant shift, from 410 to $422 \mathrm{~nm}$, in the presence of $\mathrm{KCN}$ (Fig. S1). Therefore, Y140H mutant was isolated in the ferric state. Reduction of $\mathrm{Y} 140 \mathrm{H}$ resulted in the UV-visible spectra observed in Fig. 2.

\section{Reaction of WT, Y140A, and Y140H mutants of TtH-NOX with $\mathrm{H}_{2} \mathrm{O}_{2}$ followed by UV-visible spec- troscopy}

To study the effect of $\mathrm{H}_{2} \mathrm{O}_{2}$ on $T t \mathrm{H}-\mathrm{NOX}$ protein, we monitored the changes in heme Soret during the reaction of $T t \mathrm{H}-\mathrm{NOX}$ and $\mathrm{H}_{2} \mathrm{O}_{2}$. The reaction of $5 \mu \mathrm{M} T t \mathrm{H}-\mathrm{NOX}$ with $0.1 \mathrm{mM} \mathrm{H}_{2} \mathrm{O}_{2}$ resulted in a decrease in the Soret absorbance of $T t \mathrm{H}-\mathrm{NOX}$ at $415 \mathrm{~nm}$ (Fig. 3). A $40 \%$ decrease in absorbance at $415 \mathrm{~nm}$ was observed after incubation of $T t \mathrm{H}-\mathrm{NOX}$ with $\mathrm{H}_{2} \mathrm{O}_{2}$ for $2 \mathrm{~h}$ at $25^{\circ} \mathrm{C}$. The observed rate constant for the decrease in Soret absorbance was $4.9 \pm 0.5 \times 10^{-4} \mathrm{~s}^{-1}$.

The reaction of Y140A TtH-NOX with $\mathrm{H}_{2} \mathrm{O}_{2}$ was also followed by UV-Vis spectroscopy. The reaction of $5 \mu \mathrm{M}$ Y140A $T t \mathrm{H}-\mathrm{NOX}$ with $0.1 \mathrm{mM} \mathrm{H}_{2} \mathrm{O}_{2}$ resulted in an increase in Soret absorbance at $406 \mathrm{~nm}$ (Fig. S3A). The difference spectra obtained by subtraction of the spectrum at each time point from the spectrum at time point zero are shown in Fig. S3B. Difference spectra showed appearance of a new peak at $403 \mathrm{~nm}$, which can be attributed to the formation of ferric heme by oxidation with $\mathrm{H}_{2} \mathrm{O}_{2}$. The $k_{\text {obs }}$ for the increase in $403 \mathrm{~nm}$ is $2.06 \pm 0.33 \times 10^{-4} \mathrm{~s}^{-1}$ in the presence of $0.1 \mathrm{mM}$ $\mathrm{H}_{2} \mathrm{O}_{2}$.

The reaction of $10 \mu \mathrm{M}$ ferrous $\mathrm{Y} 140 \mathrm{H} T t \mathrm{H}-\mathrm{NOX}$ with $0.1 \mathrm{mM} \mathrm{H}_{2} \mathrm{O}_{2}$ resulted in a decrease in Soret absorbance

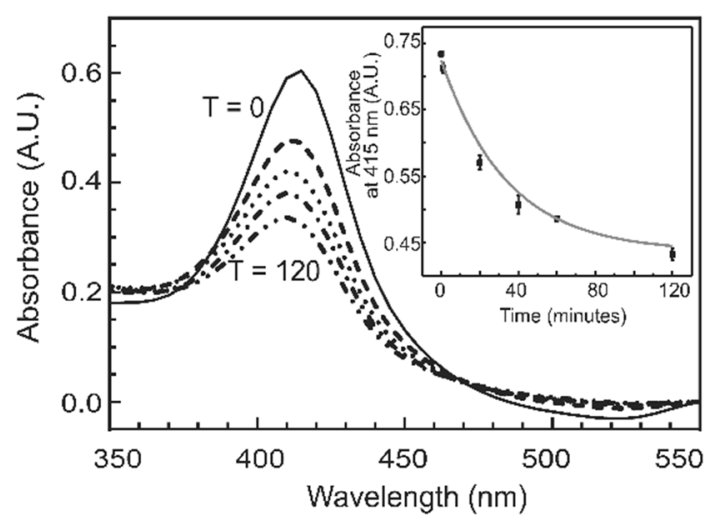

Fig. 3 Reaction between $\mathrm{H}_{2} \mathrm{O}_{2}$ and WT Tt H-NOX. $\mathrm{H}_{2} \mathrm{O}_{2}(0.1 \mathrm{mM})$ was added to WT TtH-NOX $(10 \mu \mathrm{M})$ in phosphate buffer $(50 \mathrm{mM})$ at $\mathrm{pH} 7.0$ and $25^{\circ} \mathrm{C}$. Spectra were taken at time points $0,20,40,60$, and $120 \mathrm{~min}$. Inset: Decrease in the Soret absorbance with time during the reaction of WT $T t \mathrm{H}-\mathrm{NOX}$ and $\mathrm{H}_{2} \mathrm{O}_{2}$ 


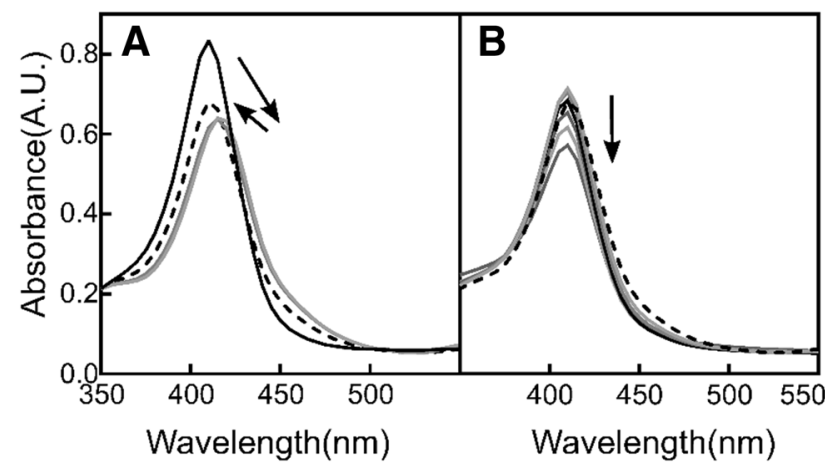

Fig. 4 a Reaction between $\mathrm{H}_{2} \mathrm{O}_{2}$ and $\mathrm{Y} 140 \mathrm{H}$ Tt $\mathrm{H}-\mathrm{NOX} . \mathrm{H}_{2} \mathrm{O}_{2}$ $(0.1 \mathrm{mM})$ was added to $\mathrm{Y} 140 \mathrm{H} T t \mathrm{H}-\mathrm{NOX}(8 \mu \mathrm{M})$ in phosphate buffer $(50 \mathrm{mM})$ at $\mathrm{pH} 7.4$ and $25{ }^{\circ} \mathrm{C}$. Spectra were taken at time points before $\mathrm{H}_{2} \mathrm{O}_{2}$ addition and 0,1 , and 4 min (dashed line). b The same sample, spectra taken at 4 (dashed line), 10, 15, 20, 30, 40, and $60 \mathrm{~min}$

at $416 \mathrm{~nm}$ (Fig. S4). Only a 10\% decrease in absorbance at $416 \mathrm{~nm}$ was observed during the reaction. The observed rate constant for the decrease in Soret absorbance was $3.5 \pm 0.9 \times 10^{-3} \mathrm{~s}^{-1}$. On the other hand, the $\mathrm{Y} 140 \mathrm{H}$ mutant in the ferric state exhibited a different reactivity with $\mathrm{H}_{2} \mathrm{O}_{2}$ when compared to the other variants and WT $T t \mathrm{H}-\mathrm{NOX}$. Addition of $\mathrm{H}_{2} \mathrm{O}_{2}$ to the protein resulted in a rapid shift of the Soret maximum absorbance from 410 to $415 \mathrm{~nm}$ initially, and then, the Soret shifted back to $410 \mathrm{~nm}$ (Fig. 4). This was followed by slow a decrease in Soret at $410 \mathrm{~nm}$. The absorbance at $415 \mathrm{~nm}$ can be interpreted as the formation of the intermediate compound II that is also observed as an intermediate in reactions of $\mathrm{Mb}$ and hemoglobin with $\mathrm{H}_{2} \mathrm{O}_{2}$ [37]. In addition, the reaction between oxidized WT $T t \mathrm{H}-\mathrm{NOX}$ and $\mathrm{H}_{2} \mathrm{O}_{2}$ was also investigated; no significant changes in the UV-Vis spectra were observed during the reaction (Fig. S5).

\section{Decomposition of $\mathrm{H}_{2} \mathrm{O}_{2}$ in the presence of WT, Y140H, and Y140A mutants of TtH-NOX}

To evaluate the catalytic potential of WT TtH-NOX towards $\mathrm{H}_{2} \mathrm{O}_{2}$ decomposition, we monitored the $\mathrm{H}_{2} \mathrm{O}_{2}$ concentration during its reaction with WT Tt $\mathrm{H}-\mathrm{NOX}$. The concentration of $\mathrm{H}_{2} \mathrm{O}_{2}$ was followed during the reaction between $10 \mu \mathrm{M} \mathrm{WT}$ Tt $\mathrm{H}-\mathrm{NOX}$ and $0.1 \mathrm{mM} \mathrm{H}_{2} \mathrm{O}_{2}$. The concentration of $\mathrm{H}_{2} \mathrm{O}_{2}$ at each time point was determined, by its oxidation of ferrous to ferric ion in the presence of xylenol orange. The effects of mutations in the distal pocket on the reaction between $\mathrm{H}_{2} \mathrm{O}_{2}$ and $T t \mathrm{H}-\mathrm{NOX}$ were also investigated by following $\mathrm{H}_{2} \mathrm{O}_{2}$ concentration similarly in the presence of $\mathrm{Y} 140 \mathrm{~A}$ and $\mathrm{Y} 140 \mathrm{H}$ (in the ferrous and ferric state) mutants of $T t \mathrm{H}-\mathrm{NOX}$. As shown in Fig. 5, the decrease in $\mathrm{H}_{2} \mathrm{O}_{2}$ concentration in the presence of WT Tt H-NOX followed exponential decay, and $93 \%$ of $\mathrm{H}_{2} \mathrm{O}_{2}$ was decomposed in $2 \mathrm{~h}$ at $25^{\circ} \mathrm{C}$. During

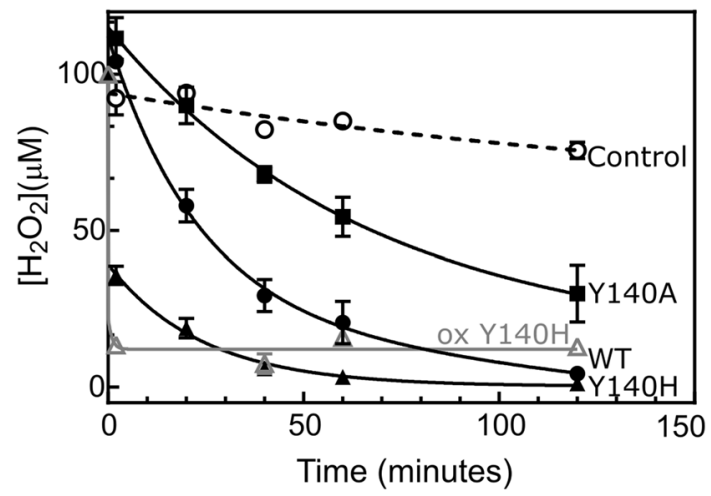

Fig. 5 Decay of $\mathrm{H}_{2} \mathrm{O}_{2}(0.1 \mathrm{mM})$ in the absence (control) and presence of WT, Y140A, reduced $\mathrm{Y} 140 \mathrm{H}(\mathrm{Y} 140 \mathrm{H})$, and ferric Y140H (ox $\mathrm{Y} 140 \mathrm{H}) T t \mathrm{H}-\mathrm{NOX}(10 \mu \mathrm{M})$. The concentration of $\mathrm{H}_{2} \mathrm{O}_{2}$ was quantified at time points $0,1,20,40,60$, and 120 min using the peroxide quantification assay

this time, only a $25 \%$ decrease in $\mathrm{H}_{2} \mathrm{O}_{2}$ concentration was observed in the absence of the protein. In the presence of Y140A TtH-NOX, only $65 \%$ of $\mathrm{H}_{2} \mathrm{O}_{2}$ was decomposed during the same time period $(2 \mathrm{~h})$. On the other hand, $90 \%$ of $\mathrm{H}_{2} \mathrm{O}_{2}$ was decomposed within the first minute in the presence of ferric Y140H Tt H-NOX (ox Y140H).

The data in Fig. 5 can fit to the first-order exponential decay to obtain a $k_{\text {obs }}$ for $0.1 \mathrm{mM} \mathrm{H}_{2} \mathrm{O}_{2}$ decay in the presence of WT, Y140A, and Y140H mutants of TtH-NOX. For the WT, Y140A, and ferric Y140H mutants of TtH-NOX, $k_{\text {obs }}$ observed is $5.7 \pm 0.7 \times 10^{-4} \mathrm{~s}^{-1}, 2.5 \pm 0.8 \times 10^{-4} \mathrm{~s}^{-1}$, and $0.035 \pm 0.02 \mathrm{~s}^{-1}$, respectively. We note that the decay in the presence of ferrous $\mathrm{Y} 140 \mathrm{H}$ does not fit to the first-order exponential decay; the fit for the second-order exponential decay is shown to guide the eye.

\section{Peroxidase activity of WT TtH-NOX}

The peroxidase activity of $T t \mathrm{H}-\mathrm{NOX}$ was investigated by following one-electron oxidation of ABTS by $\mathrm{H}_{2} \mathrm{O}_{2}$ in the presence of $T t \mathrm{H}-\mathrm{NOX}$. The reaction of $1 \mathrm{mM} \mathrm{ABTS}$ and $1 \mathrm{mM}$ $\mathrm{H}_{2} \mathrm{O}_{2}$ in the presence of $3 \mu \mathrm{M}$ WT TtHNOX at $25^{\circ} \mathrm{C}$ was followed by UV-visible spectroscopy. The spectra showed the formation of a broad band at $734 \mathrm{~nm}$ and an increase in $415 \mathrm{~nm}$ (Fig. 6a) indicative of ABTS $^{\circ+}$ formation [38]. The increase in absorbance at $734 \mathrm{~nm}$ with time was followed to obtain ABTS oxidation kinetics during this reaction as it has no significant interference from the heme absorbance (Fig. 6b). To understand the role of distal tyrosine in the peroxidase activity of $T t \mathrm{H}-\mathrm{NOX}$, ABTS oxidation was followed under the same conditions in the presence of $\mathrm{Y} 140 \mathrm{H}$ and Y140A $T t \mathrm{H}-\mathrm{NOX}$. In the presence of WT $T t \mathrm{H}-\mathrm{NOX}$, maximum absorbance at $734 \mathrm{~nm}$ was reached after $8 \mathrm{~min}$, while, in the presence of ferric $\mathrm{Y} 140 \mathrm{H} T t \mathrm{HNOX}$, the maximum absorbance was reached within the first 2 min followed by a 


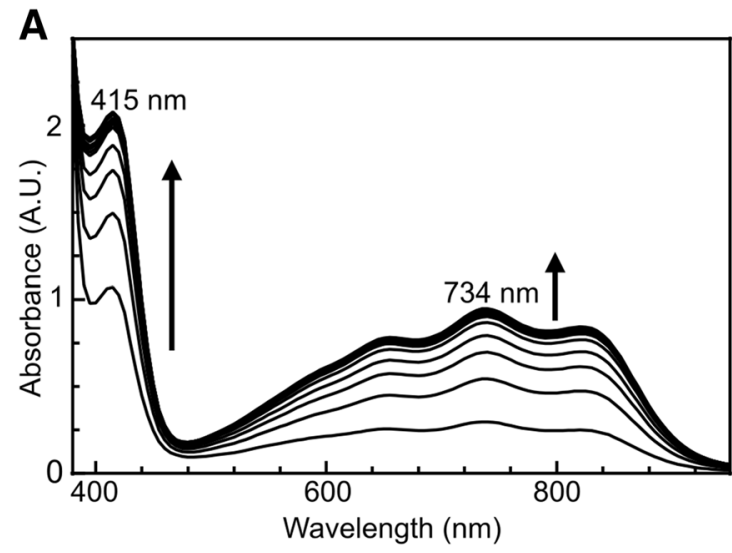

Fig. 6 a Oxidation of ABTS by $\mathrm{H}_{2} \mathrm{O}_{2}$ catalyzed by WT TtH-NOX. $\mathrm{H}_{2} \mathrm{O}_{2}(1 \mathrm{mM})$ was added to the WT TtH-NOX $(3 \mu \mathrm{M})$ and ABTS $(1 \mathrm{mM})$ mixture in phosphate buffer $(50 \mathrm{mM})$ at $\mathrm{pH} 7.5$ and $25^{\circ} \mathrm{C}$. The spectra were taken at $1 \mathrm{~min}$ intervals for $6 \mathrm{~min}$. The product for the reaction, $\mathrm{ABTS}^{-+}$, increases at $734 \mathrm{~nm}$ appears during the reaction. $\mathbf{b}$ Time course of ABTS oxidation in the presence of WT,

decrease in absorbance at $734 \mathrm{~nm}$. The decrease in $734 \mathrm{~nm}$ can be attributed to the oxidation of the $\mathrm{ABTS}^{\circ+}$ radical cation by another electron and formation of the azodication as shown in Eq. 3 [38].

$$
\mathrm{ABTS} \rightarrow \mathrm{ABTS}^{++}+\mathrm{e}^{-} \rightarrow \mathrm{ABTS}^{2+}+\mathrm{e}^{-}
$$

In the presence of ferrous $\mathrm{Y} 140 \mathrm{H}$, while the $\mathrm{ABTS}^{\cdot+}$ formation in the early time points was similar to WT, the overall yield of ABTS oxidation was $70 \%$ higher for $\mathrm{Y} 140 \mathrm{H}$ mutant.

In comparison, there was only a negligible increase in the absorbance at $734 \mathrm{~nm}$ in the presence of Y140A mutant of $T t \mathrm{H}-\mathrm{NOX}$ during this time period.

For a better kinetic analysis of the reaction, the ABTS oxidation was repeated with lower protein concentration and followed at $0.5 \mathrm{~s}$ intervals. Therefore, the reaction of $1 \mathrm{mM}$ ABTS and $1 \mathrm{mM} \mathrm{H}_{2} \mathrm{O}_{2}$ was followed in the presence of $1 \mu \mathrm{M}$ WT, and ferric and ferrous $\mathrm{Y} 140 \mathrm{H}$ mutant of $T t \mathrm{H}-\mathrm{NOX}$ at $25^{\circ} \mathrm{C}$. The formation of $\mathrm{ABTS}^{*+}$ per unit protein with time, obtained from the increase in absorbance at $734 \mathrm{~nm}$, is shown in Fig. 7. As shown in Fig. 7, the initial rate of ABTS oxidation in the presence of ferrous $\mathrm{Y} 140 \mathrm{H}$ $T t \mathrm{H}-\mathrm{NOX}\left(4 \times 10^{-7} \mathrm{M}^{-1} \mathrm{~s}^{-1}\right)$ was slightly slower than ferric $\mathrm{Y} 140 \mathrm{H}\left(5 \times 10^{-7} \mathrm{M}^{-1} \mathrm{~s}^{-1}\right)$, but five times faster compared to WT $T$ t H-NOX $\left(8 \times 10^{-8} \mathrm{M}^{-1} \mathrm{~s}^{-1}\right)$.

The peroxidase activity of the oxidized WT TtH-NOX was also investigated. The reaction of $1 \mathrm{mM}$ ABTS and $1 \mathrm{mM} \mathrm{H} \mathrm{O}_{2}$ in the presence of $3 \mu \mathrm{M}$ oxidized WT $T t \mathrm{H}$ NOX at $25^{\circ} \mathrm{C}$ was followed by UV-visible spectroscopy. Similar to WT TtH-NOX in the reduced state, an increase in $734 \mathrm{~nm}$ and $415 \mathrm{~nm}$ was observed (Fig. S6A). The increase in absorbance at $734 \mathrm{~nm}$ was slower for the oxidized state

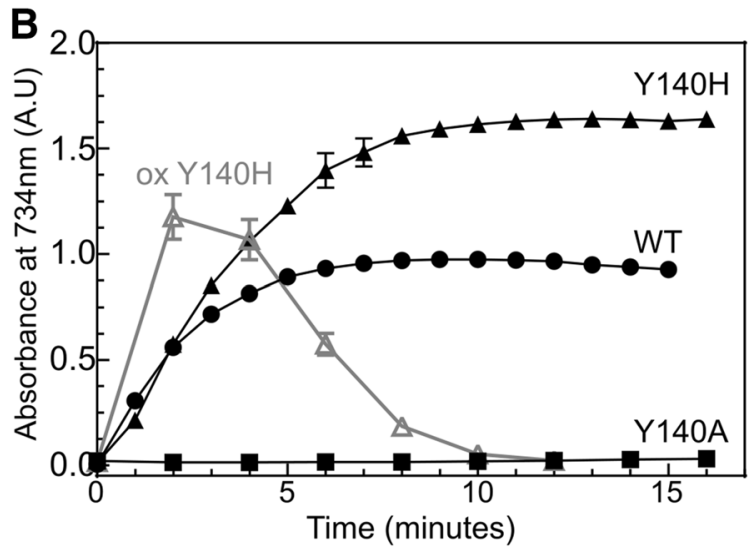

Y140A, ferrous Y140H (Y140H), and ferric Y140H (ox Y140H, gray) mutants of $T t \mathrm{H}-\mathrm{NOX}$. Formation of $\mathrm{ABTS}^{-+}$was followed by increase in absorbance at $734 \mathrm{~nm}$ during the reaction of ABTS $(1 \mathrm{mM})$ and $\mathrm{H}_{2} \mathrm{O}_{2}(1 \mathrm{mM})$ in the presence of WT $(3 \mu \mathrm{M})$, ferrous $\mathrm{Y} 140 \mathrm{H}(3 \mu \mathrm{M})$, and ferric $\mathrm{Y} 140 \mathrm{H}(3 \mu \mathrm{M})$ and $\mathrm{Y} 140 \mathrm{~A}(3 \mu \mathrm{M}) T t \mathrm{H}-$ NOX in phosphate buffer $(50 \mathrm{mM})$ at $25^{\circ} \mathrm{C}$ and $\mathrm{pH} 7.50$

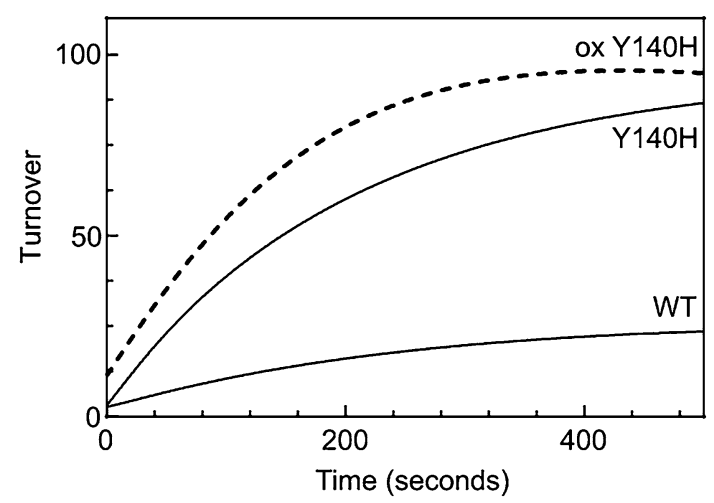

Fig. 7 Time course of ABTS oxidation catalyzed by WT, ferrous $\mathrm{Y} 140 \mathrm{H}(\mathrm{Y} 140 \mathrm{H})$, and ferric $\mathrm{Y} 140 \mathrm{H}$ (ox $\mathrm{Y} 140 \mathrm{H}$, dashed line) $T t \mathrm{H}-$ NOX. The reaction profile shows the formation of $\mathrm{ABTS}^{\bullet+}$ at $734 \mathrm{~nm}$ in the presence of WT $(1 \mu \mathrm{M})$, ferrous $\mathrm{Y} 140 \mathrm{H}(1 \mu \mathrm{M})$, ferric $\mathrm{Y} 140 \mathrm{H}$ $(1 \mu \mathrm{M}) T t \mathrm{H}-\mathrm{NOX}, \mathrm{H}_{2} \mathrm{O}_{2}(1 \mathrm{mM})$, and ABTS $(1 \mathrm{mM})$ in phosphate buffer at $\mathrm{pH} 7.50$. The $\mathrm{ABTS}^{\bullet+}$ formation was followed at $0.5 \mathrm{~s}$ intervals for $15 \mathrm{~min}$ (turnover is defined as nmol $\mathrm{ABTS}^{-+}$formed/nmol $T t \mathrm{H}-\mathrm{NOX})$

compared to the reduced state of WT TtH-NOX (Fig. S6B). Comparison of the turnover rates of oxidized WT with WT as isolated and $\mathrm{Y} 140 \mathrm{H} T t \mathrm{H}-\mathrm{NOX}$ showed that the oxidized protein has significantly lower activity (Fig. S7).

\section{Oxidation of guaiacol catalyzed by WT TtH-NOX}

The peroxidase activity of $T t \mathrm{H}-\mathrm{NOX}$ was also investigated by following oxidation of guaiacol by $\mathrm{H}_{2} \mathrm{O}_{2}$ in the presence of $T t \mathrm{H}-\mathrm{NOX}$. The reaction of $5 \mathrm{mM}$ guaiacol and $1 \mathrm{mM}$ $\mathrm{H}_{2} \mathrm{O}_{2}$ in the presence of $3 \mu \mathrm{M}$ WT TtHNOX at $25^{\circ} \mathrm{C}$ was followed by UV-visible spectroscopy. The spectra showed 
the formation of a broadband at $470 \mathrm{~nm}$ (Fig. S8), indicative of tetraguaiacol formation [33]. Kinetic analysis of the guaiacol reaction indicated that $k_{\text {cat }}$ was around $0.004 \mathrm{~s}^{-1}$ and $K_{\mathrm{M}}$ was lower than $2 \mathrm{mM}$ in the presence of $1 \mathrm{mM} \mathrm{H}_{2} \mathrm{O}_{2}$ (results not shown).

\section{Reaction kinetics of ABTS oxidation catalyzed by WT TtH-NOX}

Since the catalysis of ABTS oxidation has never been tested before on H-NOX proteins, the reaction kinetics were studied to obtain mechanistic information on the reaction. Formation of ABTS radical cation was followed at $734 \mathrm{~nm}$ during the reaction of ABTS $(0.1-1 \mathrm{mM})$ with $\mathrm{H}_{2} \mathrm{O}_{2}(1.5 \mathrm{mM})$ in the presence of WT $T t \mathrm{H}-\mathrm{NOX}(5 \mu \mathrm{M})$ to understand the reaction kinetics. The time course of $\mathrm{ABTS}^{\cdot+}$ formation did not follow simple second-order kinetics. Instead, the kinetics of this reaction proved to be complex and exhibit an initial slow phase that accelerates into a rapid phase of oxidation (Fig. 8a). As the time course of $\mathrm{ABTS}^{\circ+}$ formation is complex, it was analyzed in terms of initial rate. The dependence of initial rate on ABTS concentration is shown in Fig. 8b. Using the data at Fig. 8b, the kinetic parameters for WT $T t \mathrm{H}-\mathrm{NOX}$ were determined, $K_{M}$ was determined to be $0.74 \pm 0.13 \mathrm{mM}$, and $k_{\text {cat }}$ was $0.06 \pm 0.02 \mathrm{~s}^{-1}$ (in the presence of $1 \mathrm{mM} \mathrm{H}_{2} \mathrm{O}_{2}$ ).

\section{The pH dependence of ABTS oxidation catalyzed by WT TtH-NOX}

The $\mathrm{pH}$ dependence of the ABTS oxidation rate can be used to understand the role played by the ionizing groups in the catalytic function of the enzyme. The $\mathrm{pH}$ dependence of the ABTS oxidation was also investigated at $25^{\circ} \mathrm{C}$. The obtained

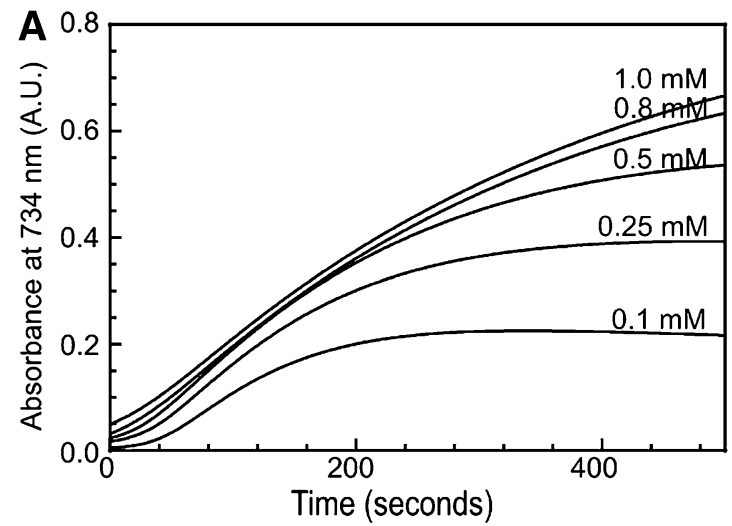

Fig. 8 a Reaction profile for ABTS oxidation at different substrate concentrations. At ABTS concentrations of 0.1, 0.25, 0.5, 0.8, and $1 \mathrm{mM}$, with $\mathrm{H}_{2} \mathrm{O}_{2}(1.5 \mathrm{mM})$ and WT Tt $\mathrm{H}-\mathrm{NOX}(3 \mu \mathrm{M})$, the oxidation reaction was followed at $734 \mathrm{~nm}$ at $0.5 \mathrm{~s}$ intervals for $15 \mathrm{~min}$ in phosphate buffer $(50 \mathrm{mM})$ at $\mathrm{pH} 7.50$ and $25^{\circ} \mathrm{C}$. b Kinetic param-

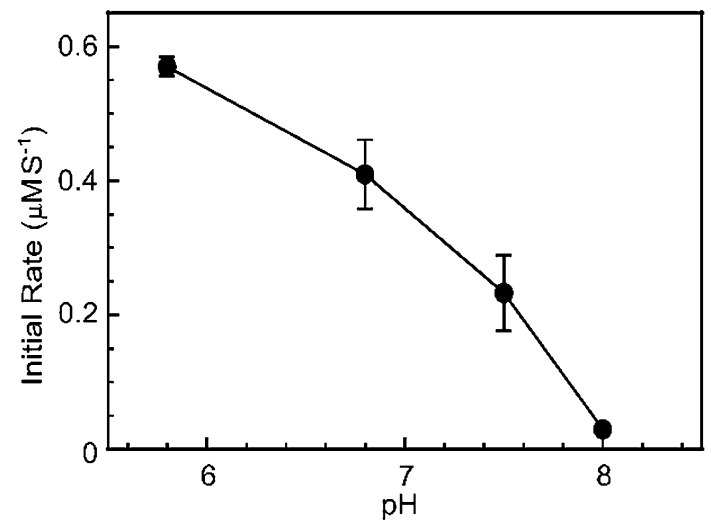

Fig. 9 Dependence of the initial rate of ABTS oxidation on $\mathrm{pH}$. The initial rate of ABTS $(1 \mathrm{mM})$ oxidation catalyzed by WT $T t \mathrm{H}$ NOX $(5 \mu \mathrm{M})$ in the presence of $\mathrm{H}_{2} \mathrm{O}_{2}(1.5 \mathrm{mM})$ in phosphate buffer $(50 \mathrm{mM})$ were determined at $\mathrm{pHs} 5.8,6.8,7.5$, and 8.0

pH profile is shown in Fig. 9, which shows an increase in the initial rate with decreasing $\mathrm{pH}$. The maximum rate observed was at $\mathrm{pH} 5.8$.

\section{Discussion}

$T t \mathrm{H}-\mathrm{NOX}$ is an ideal candidate for protein design. First, because it is well characterized, $T t \mathrm{H}-\mathrm{NOX}$ crystal structure has initially been solved to $1.77 \AA$ resolution [21]. Currently, there are 17 crystal structures of $T t \mathrm{H}-\mathrm{NOX}$ and variants in the protein data bank, which investigate a wide range of properties from oxygen binding to heme distortion and displacement of the native iron heme [39-42]. Second, it can be readily expressed in various $E$. coli strains with genetically encoded tags and purified [20,43]. In addition, it is stable

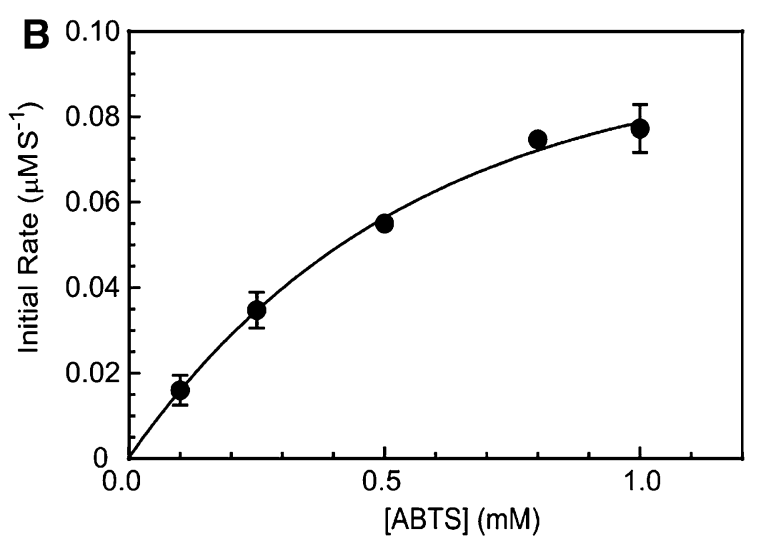

eters for ABTS oxidation reaction. The initial rate of ABTS oxidation was determined at different ABTS concentrations $(0.1-1 \mathrm{mM})$ in the presence of $\mathrm{H}_{2} \mathrm{O}_{2}(1.5 \mathrm{mM})$ and WT $T t \mathrm{H}-\mathrm{NOX}(3 \mu \mathrm{M})$ at $25.0{ }^{\circ} \mathrm{C}$ at $\mathrm{pH} 7.50$ 
under extreme temperatures (above $70{ }^{\circ} \mathrm{C}$ ) and is tolerant of site-directed mutagenesis [20, 21, 23, 24, 36]. These features can be utilized to obtain novel proteins with desired functions. Indeed, it has been shown that $T t \mathrm{H}-\mathrm{NOX}$ protein can be used as an $\mathrm{O}_{2}$ sensor and a magnetic resonance imaging (MRI) contrast agent by substitution of its native porphyrin with artificial derivatives [24, 41]. Recent studies have shown that $T t \mathrm{H}-\mathrm{NOX}$ with the native heme cofactor can be used in sensing toxic cyanide ions [36]. However, thus far, the biocatalytic potential of H-NOX proteins has not been explored. Here, for the first time, we show that WT Tt HNOX can catalyze oxidation reactions. The results clearly show that signaling protein $T t \mathrm{H}-\mathrm{NOX}$ can catalyze $\mathrm{H}_{2} \mathrm{O}_{2}$ decomposition and oxidation of ABTS by $\mathrm{H}_{2} \mathrm{O}_{2}$. In addition, the distal tyrosine (Tyr140) plays an important role in the catalysis, as mutation of Tyr140 to alanine leads to a significant decrease in catalytic activity. On the other hand, mutation of Tyr 140 to histidine resulted in a significant increase in catalytic efficiency.

The crystal structure of $\mathrm{O}_{2}$ bound $T t \mathrm{H}-\mathrm{NOX}$ has shown that the Tyr140 is involved in a hydrogen bond with the bound $\mathrm{O}_{2}$ molecule [21]. In addition, Tyr140 is conserved in anaerobic members of the H-NOX family. However, it is displaced by more hydrophobic residues in facultative aerobes and eukaryotic H-NOX proteins [34]. The previous studies have shown that mutation of Tyr140 to leucine (Y140L) resulted in reduced affinity for $\mathrm{O}_{2}$ binding to the protein [34]. This was attributed to faster dissociation rate of $\mathrm{O}_{2}$ in the absence of Tyr140. Taken together, Tyr140 is an important residue for stabilization of $\mathrm{O}_{2}$ complex in $T t \mathrm{H}-\mathrm{NOX}$ [44]. In addition, investigation of the effects of distal pocket mutations on the heme-CO vibrational modes by Resonance Raman spectroscopy revealed that Tyr 140 applies negative polarity to the distal pocket and its mutation to histidine leads to two conformers of the protein where, in both conformers, the histidine residue $\mathrm{H}$ bonds to the bound $\mathrm{CO}$ [45]. Taken together, we hypothesized that the heme chemistry could be induced toward catalysis by varying the characters of this key residue. To this end, Y140H and Y140A mutants of $T t \mathrm{H}-\mathrm{NOX}$ were expressed and isolated as previously reported for WT $T t \mathrm{H}-\mathrm{NOX}$ [21]. Unlike the previously isolated Y140L mutant, which showed a Soret maximum of $422 \mathrm{~nm}, \mathrm{Y} 140 \mathrm{H}$ mutant showed a very similar Soret absorbance to WT in the ferrous oxy state, and Y140A mutant showed maximum Soret absorbance at $409 \mathrm{~nm}$ (Fig. 2) [34]. Similar to Y140L mutant, both mutants showed modest splitting of the $\alpha / \beta$ bands. Y $140 \mathrm{H}$ mutation is more conservative compared to leucine mutation; therefore, a smaller change in the UV-Vis spectrum is expected [34]. The previous studies have shown that distal pocket steric crowding is important in determining the ligand-binding properties of H-NOX [44]. For the Y140A mutation, a larger distal cavity may lead to incorporation of a water molecule in place of tyrosine. In addition, a large increase in the Soret extinction coefficient is observed for the Y140A mutant (Fig. 2). This increase is due to a decrease in heme incorporation and the presence of apoprotein. While all proteins were expressed under the same conditions, the Y140A mutant showed a larger $280 \mathrm{~nm}$ to Soret absorbance ratio compared to WT and $\mathrm{Y} 140 \mathrm{H}$ mutant $\left(\mathrm{Abs}_{280 \mathrm{~nm}} / \mathrm{Abs}_{409 \mathrm{~nm}}\right.$ is $8,0.7$, and 0.7 for Y140A, WT, and Y140H mutant, respectively, results not shown) indicating the presence of apoprotein. Therefore, there was a decrease in heme binding in Y140A TtH-NOX due to the distal pocket mutation. We note that, in all the experiments, the holoprotein concentrations were used.

WT and Y140A $T t \mathrm{H}-\mathrm{NOX}$ were isolated in ferrous state in accordance to the previous observations. In contrast, $\mathrm{Y} 140 \mathrm{H} T t \mathrm{H}-\mathrm{NOX}$ was isolated in the ferric form. Isolation of $\mathrm{Y} 140 \mathrm{H} T t \mathrm{H}-\mathrm{NOX}$ in the ferric state can be due to increased autooxidation for this mutant. For Mb, autooxidation is proton mediated. A similar mechanism may be in play for the $\mathrm{Y} 140 \mathrm{H}$ mutant, since the distal histidine is within hydrogen-bonding distance to the bound $\mathrm{O}_{2}$, so it may promote autooxidation [46].

WT $T t \mathrm{H}-\mathrm{NOX}$ catalyzed $\mathrm{H}_{2} \mathrm{O}_{2}$ decomposition as shown in Fig. 5. Almost complete decomposition of $\mathrm{H}_{2} \mathrm{O}_{2}$ was observed in $2 \mathrm{~h}$ in the presence of WT TtH-NOX. However, this catalysis is accompanied by a decrease in the of Soret absorbance (Fig. 3). A similar decrease is observed in reactions of globins with hydrogen peroxide, which is thought to be due to oxidative modification of the protein or the heme cofactor followed by heme loss [47]. For the Y140A $T t \mathrm{H}$ NOX, reaction with $\mathrm{H}_{2} \mathrm{O}_{2}$ resulted in increase in the Soret absorbance at $403 \mathrm{~nm}$, most likely due to oxidation of the ferrous heme. The oxidation ferrous heme to ferric most likely also happens for WT TtH-NOX; however, the Soret absorbance of ferrous oxy and ferric WT $T t \mathrm{H}-\mathrm{NOX}$ is too similar to be able to follow the oxidation by UV-Vis spectroscopy (Fig. S1).

On the other hand, reaction of ferric $\mathrm{Y} 140 \mathrm{H}$ with $\mathrm{H}_{2} \mathrm{O}_{2}$ showed interesting differences compared to WT, ferrous Y140H, and Y140A TtH-NOX. An intermediate with UV absorbance at $415 \mathrm{~nm}$ was observed during the reaction, this absorbance can be attributed to compound II formation which is commonly observed in reactions between peroxidases and $\mathrm{Mb}$ with $\mathrm{H}_{2} \mathrm{O}_{2}$ [37, 48]. Ferrous $\mathrm{Y} 140 \mathrm{H}$ also shows a similar Soret maximum at $416 \mathrm{~nm}$; however, comparison of the UV-visible spectra of the intermediate with ferrous and ferric $\mathrm{Y} 140 \mathrm{H}$ suggests that intermediate compound is different from both species (Fig. S9). Compound II can be formed through homolytic cleavage of $\mathrm{H}_{2} \mathrm{O}_{2}$, or it can be formed by rapid reduction of compound I which is formed by the heterolytic cleavage of $\mathrm{H}_{2} \mathrm{O}_{2}$. Since compound I is less stable compared to compound II, its detection is more difficult. The mechanism of compound II formation for $\mathrm{Y} 140 \mathrm{H} T t \mathrm{H}-\mathrm{NOX}$ is currently unclear. This is the first 
time that a ferryl heme species is detected in the H-NOX proteins; further work is necessary to unravel the mechanism of this reaction.

Due to the critical role of Tyr140 in $\mathrm{O}_{2}$ binding to the heme and its position in the distal cavity (Fig. 1), we looked at the effects of distal tyrosine on catalytic activity. To this end, Tyr140 is mutated to alanine to eliminate any sidechain interactions. Removal of distal pocket Tyr sidechain ( $\mathrm{Y} 140 \mathrm{~A}$ ) decreased the weak intrinsic $\mathrm{H}_{2} \mathrm{O}_{2}$ decomposition activity, showing that this residue plays a role in the reaction between $\mathrm{H}_{2} \mathrm{O}_{2}$ and $T t \mathrm{H}-\mathrm{NOX}$. The $k_{\text {obs }}$ obtained for $\mathrm{H}_{2} \mathrm{O}_{2}$ decay decreased twofold when distal tyrosine is mutated to alanine. In comparison, mutation of the distal histidine in $\mathrm{Mb}$ decreased the rate of its reaction with $\mathrm{H}_{2} \mathrm{O}_{2}$ eight- to ninefold [49]. Therefore, other factors are also in play in the reaction between $\mathrm{H}_{2} \mathrm{O}_{2}$ and $T t \mathrm{H}-\mathrm{NOX}$.

To characterize the peroxidase activity of the WT $T t \mathrm{H}$ NOX and its variants, the one-electron oxidation of ABTS to the radical cation, $\mathrm{ABTS}^{-+}$, was monitored. As shown in Fig. 6b, WT TtH-NOX catalyzed ABTS oxidation, yet the Y140A TtH-NOX does not show and ABTS oxidation activity. Distal tyrosine is within hydrogen-bonding distance with the bound $\mathrm{H}_{2} \mathrm{O}_{2}$ and may play a role in $\mathrm{H}_{2} \mathrm{O}_{2}$ binding (Fig. 1). However, if this was the case, then a similar decrease should be observed in the catalysis of $\mathrm{H}_{2} \mathrm{O}_{2}$ decomposition; $\mathrm{H}_{2} \mathrm{O}_{2}$ decay rate only decreased twofold compared to WT. Therefore, the effect of Y140A mutation on ABTS oxidation cannot be simply explained by $\mathrm{H}_{2} \mathrm{O}_{2}$ binding. The generally accepted mechanism of peroxidase oxidation of substrates involves the formation of the intermediate compound I by $\mathrm{H}_{2} \mathrm{O}_{2}$, and oxidation of the substrate by compound I. Taken together, Tyr 140 most likely plays a role in stabilization of compound I intermediate rather than just $\mathrm{H}_{2} \mathrm{O}_{2}$ binding.

The histidine in the heme distal cavity of peroxidases is critical for their activity and its mutation to aliphatic residues significantly decreases compound I formation [50-52]. The distal histidine is believed to function as a general acid/ base in binding of $\mathrm{H}_{2} \mathrm{O}_{2}$ and heterolytic cleavage of the $\mathrm{O}-\mathrm{O}$ bond $[27,53]$. While $\mathrm{Mb}$ also contains a distal histidine, rational design studies have revealed that the distal histidine is too close to the heme iron to facilitate catalysis [18-20]. Indeed, proper positioning of the distal histidine in $\mathrm{Mb}$ resulted in 11-fold increase in peroxidase activity [23]. The distances between the nitrogen of the distal histidine and the ferric heme iron are normally 4.1-4.6 $\AA$ for globins and 5.5-6.0 $\AA$ for peroxidases (Fig. 1) [53]. The distance between the hydroxyl carbon in Tyr140 and the heme iron is $5.8 \AA$. Therefore, mutation of this residue to histidine is expected to result in a histidine residue located in similar distance to the heme cofactor as in distal histidine in peroxidases. To remodel the $T t \mathrm{H}-\mathrm{NOX}$ distal pocket towards a peroxidase architecture, we substituted Tyr140 with His.
Indeed, $\mathrm{Y} 140 \mathrm{H}$ mutant showed a significant acceleration in $\mathrm{H}_{2} \mathrm{O}_{2}$ decomposition compared to wild type (Fig. 5). In addition, $\mathrm{Y} 140 \mathrm{H} T t \mathrm{H}-\mathrm{NOX}$ showed significantly higher ABTS oxidation compared to WT, as shown in Fig. 6b. Indeed, the initial rate of ABTS oxidation was five times faster in the presence of $\mathrm{Y} 140 \mathrm{H}$ mutant compared to wild type under the same conditions (Fig. 7). Therefore, addition of the histidine as an acid/base catalyst to the active site improved peroxidase activity. The ferric $\mathrm{Y} 140 \mathrm{H}$ TtH-NOX shows higher activity than the ferrous protein in both decomposition of $\mathrm{H}_{2} \mathrm{O}_{2}$ and oxidation of ABTS. This indicates that reaction of ferrous $\mathrm{Y} 140 \mathrm{H} T t \mathrm{H}-\mathrm{NOX}$ with $\mathrm{H}_{2} \mathrm{O}_{2}$ is slower compared to its reaction with the ferric protein.

The activity for oxidation of ABTS was also monitored for oxidized (ferric) WT $T t \mathrm{H}$-NOX. Oxidized WT TtH-NOX showed significantly lower activity compared to the ferrous oxy state of the protein. Since $\mathrm{H}_{2} \mathrm{O}_{2}$ is a two-electron acceptor, its reaction with ferrous $\mathrm{Mb}$ and hemoglobin results in the formation of compound II, which can react with a substrate, or further react with $\mathrm{H}_{2} \mathrm{O}_{2}$ to produce ferric protein and superoxide [37]. The reaction of $\mathrm{H}_{2} \mathrm{O}_{2}$ with ferric $\mathrm{Mb}$ is initially thought to result in a transient compound I like product which is rapidly reduced to compound II by abstracting an electron from residues in the apoprotein [54]. Compound II reacts with substrates or $\mathrm{H}_{2} \mathrm{O}_{2}$ to reduce back to ferric state. If a similar mechanism is in play for $T t \mathrm{H}-$ NOX proteins, then completion of catalytic cycle and high turnover numbers can only be achieved if the ferric protein has similar activity to ferrous protein. The lower activity observed for oxidized WT TtH-NOX is inconsistent with this mechanism. Two possible factors may be responsible for this result: an alternative mechanism that results in partial reduction to ferrous $T t \mathrm{H}-\mathrm{NOX}$ is responsible for catalysis in this system, or the conformation and activity of ferric $T t \mathrm{H}-\mathrm{NOX}$ obtained by ferricyanide oxidation is significantly different from the ferric $T t \mathrm{H}-\mathrm{NOX}$ resulting from the oxidation by $\mathrm{H}_{2} \mathrm{O}_{2}$.

Since the catalysis of ABTS oxidation has never been tested before on H-NOX proteins, the reaction kinetics was also studied. Formation of $\mathrm{ABTS}^{\cdot+}$ was followed at various concentrations of ABTS in the presence of excess $\mathrm{H}_{2} \mathrm{O}_{2}$ (Fig. 8a). The oxidation of ABTS did not follow simple second-order kinetics in the presence of WT TtH-NOX, the increase in $734 \mathrm{~nm}$ absorbance was initially slow, and as the reaction proceeded, the rate increased with time giving a sigmoidal kinetic curve. A similar lag phase was also observed for oxidation of guaiacol (Figure S10), so this kinetic behavior is not dependent on substrate. The reason for the lag phase is currently unclear; more kinetic studies need to be done to decipher reactive intermates and the mechanism of this reaction.

Analysis of initial rate vs substrate concentration showed classical Michaelis-Menten kinetics (Fig. 8b). Based on the 
initial rate results, the kinetic parameters for WT $T t \mathrm{H}-\mathrm{NOX}$ were determined, $K_{\mathrm{M}}$ was determined to be $0.74 \pm 0.13 \mathrm{mM}$, and $k_{\text {cat }}$ was $0.06 \pm 0.02 \mathrm{~s}^{-1}$ for $1.5 \mathrm{mM} \mathrm{H}_{2} \mathrm{O}_{2}$. Therefore, the catalytic efficiency for $T t \mathrm{H}-\mathrm{NOX}$ is $0.08 \mathrm{~s}^{-1} \mathrm{mM}^{-1}$. The $T t \mathrm{H}-\mathrm{NOX} K_{\mathrm{M}}$ for ABTS is comparable to native HRP, which is interesting as native $T t \mathrm{H}-\mathrm{NOX}$ does not to have catalytic function [55]. However, as expected, the turnover number is significantly lower than peroxidases which show $300-4000 \mathrm{~s}^{-1}$ turnover number in the presence of $10 \mathrm{mM}$ $\mathrm{H}_{2} \mathrm{O}_{2}$. On the other hand, $T t \mathrm{H}-\mathrm{NOX}$ proteins are more efficient at oxidation of substrates by $\mathrm{H}_{2} \mathrm{O}_{2}$ compared to native oxidation catalysts such as cytochrome P450 enzymes (P450s) $\left[k_{\text {cat }}<0.008 \mathrm{~s}^{-1}\right.$ for cytochrome P450BM-3 with $p$-nitrophenoxydodecanoic acid (12-pNCA) as substrate] [56]. Indeed, the initial rates observed for the oxidation by $T t \mathrm{H}-\mathrm{NOX}$ is comparable to $\mathrm{P} 450$ s engineered for peroxidedriven hydroxylation (initial rate $2.4 \mathrm{~min}^{-1}$ for HF87A with styrene as substrate, compared to $1.6 \mathrm{~min}^{-1}$ for WT TtHNOX) [57]. In addition, the $K_{\mathrm{M}}$ and $k_{\text {cat }}$ for $T t \mathrm{H}-\mathrm{NOX}$ is comparable to native myoglobin which is commonly used as a protein scaffold for rational design (approximately $0.08 \mathrm{mM}$, and $0.4 \mathrm{~s}^{-1}$, at $20^{\circ} \mathrm{C}$, respectively) [53]. In addition to ABTS, WT $T t \mathrm{H}-\mathrm{NOX}$ also catalyzed oxidation of guaiacol by $\mathrm{H}_{2} \mathrm{O}_{2}$; however, the $k_{\text {cat }}$ for guaiacol was tenfold lower compared to ABTS.

The rate of ABTS oxidation catalyzed by $T t \mathrm{H}-\mathrm{NOX}$ increased with decreasing $\mathrm{pH}$ (Fig. 9). This result shows that at least one ionizing group in the active site affects the oxidation reaction rate and the rate of oxidation is maximum when this group is in the protonated form [49]. This result implies that, like peroxidases, an acid/base catalyst may play a role in the peroxidase activity. Furthermore, this proton donor is not Tyr140 alone, since the $\mathrm{pH}$ profile does not fit to a tyrosine residue which has a $\mathrm{p} K_{\mathrm{a}}$ of 9.11 . A similar $\mathrm{pH}$ profile was observed for Mb oxidation of ABTS [58]. One difference between $\mathrm{Mb}$ and $T t \mathrm{H}-\mathrm{NOX}$ is the heme coordination in the ferric state of the protein. For metMb, the sixth ligand of the ferric iron at neutral $\mathrm{pH}$ is aqua $\left(\mathrm{H}_{2} \mathrm{O}\right)$. Indeed, the $\mathrm{p} K_{\mathrm{a}}$ of the distal water in metMb is $8.8[59,60]$. On the other hand, the distal ligand in ferric $T t \mathrm{H}-\mathrm{NOX}$ at neutral $\mathrm{pH}$ is $\mathrm{OH}^{-}$, and the $\mathrm{p} K_{\mathrm{a}}$ for the distal aqua ligand is 6.8 [61]. One reason for the increase in activity at lower $\mathrm{pH}$ can also be due to the ligand change in the ferric iron coordination.

\section{Conclusion}

In summary, we have shown that thermophilic hemoprotein $T t \mathrm{H}-\mathrm{NOX}$ can catalyze $\mathrm{H}_{2} \mathrm{O}_{2}$ decomposition and oxidation of ABTS and guaiacol. While $T t \mathrm{H}-\mathrm{NOX}$ has a very different distal pocket environment compared to $\mathrm{Mb}$, it can catalyze these reactions with comparable efficiency. $T t \mathrm{H}-\mathrm{NOX}$ does not have any histidine residues in the distal pocket; instead,
Tyr140 was shown to be involved in hydrogen bonding with bound molecular oxygen. We show that Tyr 140 also plays a role in the catalysis, as the mutation of this residue to alanine significantly impairs catalytic activity. On the other hand, mutation of the distal tyrosine in $T t \mathrm{H}-\mathrm{NOX}$ to histidine, observed in peroxidases and myoglobin, increases oxidation activity significantly. This result supports the conclusions from the previous studies on the role of distal histidine in the cleavage of the $\mathrm{O}-\mathrm{O}$ bond found in $\mathrm{H}_{2} \mathrm{O}_{2}$. In addition, we show that, while distal histidine plays an important role in hemoprotein reactions with $\mathrm{H}_{2} \mathrm{O}_{2}$, it is not always essential for oxidation activity. Reaction of $\mathrm{Y} 140 \mathrm{H}$ with $\mathrm{H}_{2} \mathrm{O}_{2}$ leads to a compound II like intermediate, which is observed for the first time in H-NOX proteins. This study introduces $T t \mathrm{H}-\mathrm{NOX}$ protein as an ideal scaffold for design of novel biocatalysts due to its robust nature and ease of expression and purification. Future studies will focus on exploring the catalytic potentials of various $T t \mathrm{H}-\mathrm{NOX}$ mutants in hopes of discovering novel biocatalysts.

Acknowledgements This work was supported by The Scientific and Technological Research Council of Turkey (TUBITAK, 115C134). We thank Dr. Michael A. Marletta for the generous gift of pET20b plasmid encoding WT $T t \mathrm{H}-\mathrm{NOX}$. We thank Dr. Eric S. Underbakke for critical reading of the manuscript. J.E.A-F. received financial support from Turkiye Scholarships. We thank Belgin Tunçel Kırkar and the Department of Chemical Engineering at Izmir Institute of Technology for their help with the glovebox instrument. We are thankful to Biotechnology and Bioengineering Application and Research Center at Izmir Institute of Technology for DNA sequencing analysis.

\section{References}

1. Poulos TL (2014) Heme enzyme structure and function. Chem Rev 114:3919-3962. https://doi.org/10.1021/cr400415k

2. Olson JS, Eich RF, Smith LP et al (1997) Protein engineering strategies for designing more stable hemoglobin-based blood substitutes. Artif Cells Blood Substit Biotechnol 25:227-241. https:// doi.org/10.3109/10731199709118912

3. Isaac IS, Dawson JH (1999) Haem iron-containing peroxidases. Essays Biochem 34:51-69

4. Park SY, Shimizu H, Adachi S et al (1997) Crystal structure of nitric oxide reductase from denitrifying fungus Fusarium oxysporum. Nat Struct Biol 4:827-832

5. Pellequer J-L, Brudler R, Getzoff ED (1999) Biological sensors: more than one way to sense oxygen. Curr Biol 9:R416-R418. https://doi.org/10.1016/S0960-9822(99)80257-7

6. Jain R, Chan MK (2003) Mechanisms of ligand discrimination by heme proteins. J Biol Inorg Chem 8:1-11. https://doi.org/10.1007/ s00775-002-0405-8

7. Ozaki S, Matsui T, Roach MP, Watanabe Y (2000) Rational molecular design of a catalytic site: engineering of catalytic functions to the myoglobin active site framework. Coord Chem Rev 198:39-59. https://doi.org/10.1016/S0010-8545(00)00234-4

8. Lu Y, Berry SM, Pfister TD (2001) Engineering novel metalloproteins: design of metal-binding sites into native protein scaffolds. Chem Rev 101:3047-3080. https://doi.org/10.1021/cr0000574

9. Colonna S, Gaggero N, Richelmi C, Pasta P (1999) Recent biotechnological developments in the use of peroxidases. 
Trends Biotechnol 17:163-168. https://doi.org/10.1016/S0167 -7799(98)01288-8

10. Alvarado B, Torres E (2009) Recents patents in the use of peroxidases. Recent Pat Biotechnol 3:88-102

11. Schonbaum GR, Chance B (1976) The enzymes. Catalase 7:363-408

12. Matsui T, Ozaki S, Watanabe Y (1999) Formation and catalytic roles of compound I in the hydrogen peroxide-dependent oxidations by His64 myoglobin mutants. J Am Chem Soc 121:99529957. https://doi.org/10.1021/ja9914846

13. Battistuzzi G, Bellei M, Bortolotti CA, Sola M (2010) Redox properties of heme peroxidases. Arch Biochem Biophys 500:21-36. https://doi.org/10.1016/j.abb.2010.03.002

14. Yu F, Cangelosi VM, Zastrow ML et al (2014) Protein design: toward functional metalloenzymes. Chem Rev 114:3495-3578. https://doi.org/10.1021/cr400458x

15. Chand S, Ray $S$, Wanigasekara $E$ et al (2018) Improved rate of substrate oxidation catalyzed by genetically-engineered myoglobin. Arch Biochem Biophys 639:44-51. https://doi. org/10.1016/j.abb.2017.12.014

16. Matsuo T, Fukumoto K, Watanabe T, Hayashi T (2011) Precise design of artificial cofactors for enhancing peroxidase activity of myoglobin: myoglobin mutant H64D reconstituted with a "single-winged cofactor" is equivalent to native horseradish peroxidase in oxidation activity. Chemistry 6:2491-2499. https ://doi.org/10.1002/asia.201100107

17. Sato H, Hayashi T, Ando T et al (2004) Hybridization of modified-heme reconstitution and distal histidine mutation to functionalize sperm whale myoglobin. J Am Chem Soc 126:436437. https://doi.org/10.1021/ja038798k

18. Iyer LM, Anantharaman V, Aravind L (2003) Ancient conserved domains shared by animal soluble guanylyl cyclases and bacterial signaling proteins. BMC Genom 4:5. https://doi. org/10.1186/1471-2164-4-5

19. Schmidt PM, Schramm M, Schröder H et al (2004) Identification of residues crucially involved in the binding of the heme moiety of soluble guanylate cyclase. J Biol Chem 279:3025-3032. https ://doi.org/10.1074/jbc.M310141200

20. Karow DS, Pan D, Tran R et al (2004) Spectroscopic characterization of the soluble guanylate cyclase-like heme domains from Vibrio cholerae and Thermoanaerobacter tengcongensis. Biochemistry 43:10203-10211. https://doi.org/10.1021/bi049 3741

21. Pellicena P, Karow DS, Boon EM et al (2004) Crystal structure of an oxygen-binding heme domain related to soluble guanylate cyclases. Proc Natl Acad Sci USA 101:12854-12859. https://doi. org/10.1073/pnas.0405188101

22. Martin E, Berka V, Bogatenkova E et al (2006) Ligand selectivity of soluble guanylyl cyclase: effect of the hydrogen-bonding tyrosine in the distal heme pocket on binding of oxygen, nitric oxide, and carbon monoxide. J Biol Chem 281:27836-27845. https://doi. org/10.1074/jbc.M601078200

23. Olea C, Boon EM, Pellicena P et al (2008) Probing the function of heme distortion in the H-NOX family. ACS Chem Biol 3:703-710. https://doi.org/10.1021/cb800185h

24. Winter MB, McLaurin EJ, Reece SY et al (2010) Ru-porphyrin protein scaffolds for sensing $\mathrm{O}_{2}$. J Am Chem Soc 132:5582-5583. https://doi.org/10.1021/ja101527r

25. Poulos TL, Sheriff S, Howard AJ (1987) Cocrystals of yeast cytochrome c peroxidase and horse heart cytochrome c. J Biol Chem 262:13881-13884

26. Dawson JH (1988) Probing structure-function relations in hemecontaining oxygenases and peroxidases. Science 240:433-439

27. Poulos T, Kraut J (1980) A hypothetical model of the cytochrome c peroxidase cytochrome c electron transfer complex. J Biol Chem 255:10322-10330
28. Gajhede M, Schuller DJ, Henriksen A et al (1997) Crystal structure of horseradish peroxidase $\mathrm{C}$ at 2.15 A resolution. Nat Struct Biol 4:1032-1038

29. Phillips GN, Arduini RM, Springer BA, Sligar SG (1990) Crystal structure of myoglobin from a synthetic gene. Proteins 7:358-365. https://doi.org/10.1002/prot.340070407

30. Weinert EE, Plate L, Whited CA et al (2010) Determinants of ligand affinity and heme reactivity in H-NOX domains. Angew Chemie Int Ed 49:720-723. https://doi.org/10.1002/anie.20090 4799

31. Barr I, Guo F (2015) Pyridine hemochromagen assay for determining the concentration of heme in purified protein solutions. Bio Protoc 5:7-20. https://doi.org/10.21769/BioProtoc.1594

32. Re R, Pellegrini N, Proteggente A et al (1999) Antioxidant activity applying an improved ABTS radical cation decolorization assay. Free Radic Biol Med 26:1231-1237

33. Chance B, Maehly AC (1955) [136] Assay of catalases and peroxidases. Methods Enzymol 2:764-775. https://doi.org/10.1016/ S0076-6879(55)02300-8

34. Boon EME, Huang SH, Marletta MAMMA (2005) A molecular basis for NO selectivity in soluble guanylate cyclase. Nat Chem Biol 1:53-59. https://doi.org/10.1038/nchembio704

35. Boon EM, Marletta MA (2005) Ligand discrimination in soluble guanylate cyclase and the H-NOX family of heme sensor proteins. Curr Opin Chem Biol 9:441-446. https://doi.org/10.1016/j. cbpa.2005.08.015

36. Dai Z, Boon EM (2010) Engineering of the Heme pocket of an $\mathrm{H}-\mathrm{NOX}$ domain for direct cyanide detection and quantification. $\mathrm{J}$ Am Chem Soc 132:11496-11503. https://doi.org/10.1021/ja101 $674 \mathrm{z}$

37. Richards MP (2013) Redox reactions of myoglobin. Antioxid Redox Signal 18:2342-2351. https://doi.org/10.1089/ ars.2012.4887

38. Childs BRE, Bardsley WG (1975) The steady-state kinetics of peroxidase with 2,2'-azino-di-(3-ethylbenzothiazoline- 6-sulphonic acid) as chromogen. Biochem J 145:93-103. https://doi. org/10.1042/bj1450093

39. Hespen CW, Bruegger JJ, Phillips-Piro CM, Marletta MA (2016) Structural and functional evidence indicates selective oxygen signaling in Caldanaerobacter subterraneus H-NOX. ACS Chem Biol 11:2337-2346. https://doi.org/10.1021/acschembio.6b00431

40. Weinert EE, Phillips-Piro CM, Marletta MA (2013) Porphyrin $\pi$-stacking in a heme protein scaffold tunes gas ligand affinity. J Inorg Biochem 127:7-12. https://doi.org/10.1016/j.jinor gbio.2013.06.004

41. Winter MB, Klemm PJ, Phillips-Piro CM et al (2013) Porphyrin-substituted $\mathrm{H}-\mathrm{NOX}$ proteins as high-relaxivity MRI contrast agents. Inorg Chem 52:2277-2279. https://doi.org/10.1021/ic302 $685 \mathrm{~h}$

42. Winter MB, Herzik MA, Kuriyan J, Marletta MA (2011) Tunnels modulate ligand flux in a heme nitric oxide/oxygen binding (H-NOX) domain. Proc Natl Acad Sci 108:E881-E889. https:// doi.org/10.1073/pnas.1114038108

43. Winter MB, Woodward JJ, Marletta MA (2013) An Escherichia coli expression-based approach for porphyrin substitution in heme proteins. Methods Mol Biol 987:95-106. https://doi. org/10.1007/978-1-62703-321-3-8

44. Kosowicz JG, Boon EM (2013) Insights into the distal heme pocket of $\mathrm{H}-\mathrm{NOX}$ using fluoride as a probe for $\mathrm{H}$-bonding interactions. J Inorg Biochem 126:91-95. https://doi.org/10.1016/j.jinor gbio.2013.05.012

45. Tran R, Weinert EE, Boon EM et al (2011) Determinants of the heme-CO vibrational modes in the H-NOX family. Biochemistry 50:6519-6530

46. Brantley RE, Smerdon SJ, Wilkinson AJ et al (1993) The mechanism of autooxidation of myoglobin. J Biol Chem 268:6995-7010 
47. Yeh L-H, Alayash AI (2003) Redox side reactions of haemoglobin and cell signalling mechanisms. J Intern Med 253:518-526

48. Yonetani T, Schleyer H (1969) Studies on cytochrome c peroxidase IX. The reaction of ferrimyoglobin with hydroperoxides and a comparison of peroxide-induced compounds of ferrimyoglobin and cytochrome c peroxidase. J Biol Chem 242:1947-1979

49. Khan KK, Mondal MS, Padhy L, Mitra S (1998) The role of distal histidine in peroxidase activity of myoglobin. Eur J Biochem 257:547-555. https://doi.org/10.1046/j.1432-1327.1998.25705 47. $\mathrm{x}$

50. Edwards SL, Raag R, Wariishi H et al (1993) Crystal structure of lignin peroxidase. Proc Natl Acad Sci USA 90:750-754. https:// doi.org/10.1006/jmbi.1998.2507

51. Erman JE, Vitello LB, Miller MA et al (1993) Histidine 52 is a critical residue for rapid formation of cytochrome $\mathrm{c}$ peroxidase compound I. Biochemistry 32:9798-9806. https://doi. org/10.1021/bi00088a035

52. Newmyer SL, Ortiz de Montellano PR (1995) Horseradish peroxidase His- $42 \rightarrow$ Ala, His- $42 \rightarrow$ Val, and Phe- $41 \rightarrow$ Ala mutants. Histidine catalysis and control of substrate access to the heme iron. J Biol Chem 270:19430-19438. https://doi.org/10.1074/ jbc.270.33.19430

53. Matsui T, Ozaki SI, Liong E et al (1999) Effects of the location of distal histidine in the reaction of myoglobin with hydrogen peroxide. J Biol Chem 274:2838-2844. https://doi.org/10.1074/ jbc.274.5.2838

54. Giulivi C, Davies KJA (1994) [30] Hydrogen peroxide-mediated ferrylhemoglobin generation in vitro and in red blood cells.
Methods Enzymol 231:490-496. https://doi.org/10.1016/00766879(94)31032-7

55. Savenkova MI, Kuo JM, Ortiz de Montellano PR (1998) Improvement of peroxygenase activity by relocation of a catalytic histidine within the active site of horseradish peroxidase. Biochemistry 37:10828-10836. https://doi.org/10.1021/bi9725780

56. Li QS, Ogawa J, Shimizu S (2001) Critical role of the residue size at position 87 in $\mathrm{H}_{2} \mathrm{O}_{2}$-dependent substrate hydroxylation activity and $\mathrm{H}_{2} \mathrm{O}_{2}$ inactivation of cytochrome P450BM-3. Biochem Biophys Res Commun 280:1258-1261. https://doi.org/10.1006/ bbrc.2001.4261

57. Cirino PC, Arnold FH (2003) A self-sufficient peroxide-driven hydroxylation biocatalyst. Angew Chem Int Ed Engl 42:32993301. https://doi.org/10.1002/anie.200351434

58. Carlsen CU, Skovgaard IM, Skibsted LH (2003) Pseudoperoxidase activity of myoglobin: kinetics and mechanism of the peroxidase cycle of myoglobin with $\mathrm{H}_{2} \mathrm{O}_{2}$ and 2,2-azino-bis(3-ethylbenzothiazoline-6-sulfonate) as substrates. J Agric Food Chem 51:58155823. https://doi.org/10.1021/jf030067g

59. George P, Hanania G (1952) The Ionization of acidic metmyoglobin. Biochem J 52:517-523. https://doi.org/10.1042/bj0650756

60. Svistunenko DA, Sharpe MA, Nicholls P et al (2000) The pH dependence of naturally occurring low-spin forms of methaemoglobin and metmyoglobin: an EPR study. Biochem J 351:595-605. https://doi.org/10.1042/0264-6021:3510595

61. Olea C, Kuriyan J, Marletta MA (2010) Modulating heme redox potential through protein-induced porphyrin distortion. J Am Chem Soc 132:12794-12795. https://doi.org/10.1021/ja106252b

\section{Affiliations}

\section{Joana Efua Aggrey-Fynn ${ }^{1}$. Nur Basak Surmeli ${ }^{2}$}

Nur Basak Surmeli

nursurmeli@iyte.edu.tr

1 Department of Molecular Biology and Genetics, İzmir Institute of Technology, Gülbahce, Urla, Izmir, Turkey
Department of Bioengineering, Izmir Institute of Technology, Fen Fak. A Blok Oda 205, Gülbahce, Urla, Izmir, Turkey 